pISSN : 1979-0694

\title{
KOMPUTERISASI BARANG INVENTARIS PADA KANTOR LINGKUNGAN HIDUP KOTA DUMAI
}

\author{
Arges Cilla Mondev ${ }^{1}$, Asparizal ${ }^{2}$, Sukri Adrianto ${ }^{3}$ \\ Sekolah Tinggi Manajemen Informatika dan Komputer (STMIK) Dumai \\ Jl. Utama Karya Bukit Batrem, Dumai, Kode Pos : 28811 \\ Email : asparizal73@gmail.com
}

\begin{abstract}
ABSTRAK
Setiap instansi/lembaga baik pemerintah maupun swasta pasti memiliki barang inventaris. Barang inventaris adalah daftar yang memuat semua barang milik kantor yang dipakai untuk melaksanakan tugas. Sebuah instansi tidak akan terlepas dari persoalan inventaris, begitu juga dengan kantor lingkungan hidup kota Dumai yangmempunyai barang inventaris cukup banyak untuk di inventarisasikan. Dari hasil observasi yang penulis lakukan terdapat beberapa permasalahan antara lain pengolahan data inventaris dilakukan secara manual, yakni belum menggunakan database sebagai penyimpanan data, membutuhkan waktu yang lama dalam mengolah data karena data inventaris yang terdaftar tersebut dientrikan ke komputer memakai microsoft excel tanpa menggunakan database.Sebagai solusinya penerapan sistem komputerisasi inventaris barang yang berbasis database perlu dilakukan sehingga penata-usahaan inventaris barang milik/kekayaan negara dapat berjalan secara optimal.Metode yang digunakan dalam pengembangan sistem ini adalah model Waterfall. Output yang dihasilkan berupa laporan-laporan yang lebih cepat, tepat dan akurat bagi semua yang berkepentingan terutama pimpinan untuk pertanggungjawaban dan pengambilan keputusan.
\end{abstract}

Kata Kunci : Komputerisasi,Inventarisasi, Database

\section{PENDAHULUAN}

\subsection{Latar Belakang}

Komputer dapat digunakan untuk mengolah data yang menghasilkan informasi. Hampir semua instansi menggunakan komputer dalam mengolah data. Salah satu kegiatan dalam instansi pemerintah yang menggunakan komputer dalam mengolah data ialah kegiatan inventarisasi barang.

Dari observasi serta wawancara yang dilakukandi Kantor Lingkungan Hidup (KLH) kota Dumai,terdapat data inventaris barang yang belum mempunyai sistem komputerisasi. Ini dapat dilihat dari beberapa permasalahanantara lain pengolahan data inventaris masih dilakukan secara manual,yakni belum menggunakan database sebagai penyimpanan data. Membutuhkan waktu yang lama dan tenaga yang banyak karena data inventaris yang terdaftar tersebut dientrikan ke komputer memakai Microsoft Excel tanpa menggunakan database. Setelah data dientrikan di komputer, petugas mencetak hardcopynya dan disimpan didalam lemari arsip atau rak-rak arsip.Pada saat data inventaris tersebut diperlukan, petugas sibuk mencari arsipnya dengan memeriksa satu per satu rak-rak arsip yang dijadikan untuk menyimpan arsip data inventaris tersebut. Berdasarkan permasalahan tersebut diatas maka penulis mencoba merancang sebuah sistem komputerisasi yang dapat menghasilkan laporan yang efektif dan efesien tentang data inventarisbarangseperti, mengetahui data inventaris barang,menyajikan laporan penerimaan barang, laporan Kartu Inventaris Barang (KIB), laporan Kartu Inventaris Ruangan (KIR), laporan stiker barang, laporan keadaan barang dengan cepat sehingga pengambilan keputusan dapat dilakukan lebih cepat, dan mempermudah dalam proses back up data.Dengan diterapkan sistem komputerisasi ini juga memberikan kemudahan tentang pengolahan data bagi petugas inventaris.

\subsection{Tujuan dan Manfaat Penelitian}

Tujuan dari penelitian ini adalah;

1. Mengetahui bagaimana jalannya sistem pengelolaan data inventaris selama ini pada KLH kota Dumai.

2. Menganalisa sistem pengelolaan inventaris yang sedang berjalan untuk dirancang sebuah sistem komputerisasi data inventaris menggunakan database.

3. Menguji penelitian dengan menggunakan bahasa pemrograman Visual Basic.net dan database $M y S Q L$

4. Mempermudah pengelolaan data inventaris dengan efektif dan efesien.

5. Agar pimpinan lebih cepat mendapatkan informasi mengenai data barang inventaris, serta memudahkan dalam pengambilan keputusan.

6. Agar dapat mengetahui semua informasi yang berkaitan dengan data inventaris dengan cepat, tepat dan akurat. 
INFORMA TIK

Jurnal Informatika, Manajemen Dan Komputer Vol. 9 No. 1, Mei 2017

eISSN : 2580-3042

pISSN : 1979-0694

\subsection{Tinjauan Pustaka}

1) Inventarisasi

Inventarisasi adalah kegiatan atau tindakan untuk melakukan perhitungan, pengurusan, penyelenggaraan, pengaturan, pencatatan, data dan pelaporan barang milik daerah dalam unit pemakaian ( Soleh Chabib, dkk 2010 : 180 ). Barang inventaris adalah seluruh barang yang dimiliki oleh pemerintah daerah yang penggunaannya lebih dari satu tahun dan dicatat serta didaftar dalam buku inventaris. (Permendagri no.17 tahun 2007). Adapun pengertian Barang Milik Daerah sebagaimana yang diatur dalam Pasal 3 butir 1 huruf a,b dan butir 2 huruf a, b, c, d Peraturan Menteri Dalam Negeri Nomor 17 Tahun 2007 tentang Pedoman Teknis Pengelolaan barang Milik Daerah bahwa Barang Milik Daerah adalah Barang yang dibeli atau diperoleh atas beban APBD, barang yang berasal dari perolehan lainnya yang sah. Barang sebagaimana dimaksud meliputi :

1. Barang yang diperoleh dari hibah/sumbangan atau yang sejenis;

2. Barang yang diperoleh sebagai pelaksanaan dari perjanjian/kontrak;

3. Barang yang diperoleh berdasarkan ketentuan undang-undang; atau

4. Barang yang diperoleh berdasarkan putusan pengadilan yang telah memperoleh kekuatan hukum tetap. (Pasal 3 Peraturan Menteri Dalam Negeri Nomor 17 tahun 2007 : 6).

\section{2) Visual Basic.Net}

Visual Basic merupakan salah satu bahasa pemrograman yang andal dan banyak digunakan oleh pengembang untuk membangun berbagai macam aplikasi windows. Visual Basic 2008atau Visual Basic 9 adalah versi terbaru yang telah diluncurkan oleh Microsoft bersama C\#, $C++$, dan Visual Web Developer dalam satu paket Visual Studio 2008 (Wahana Komputer,2010:h.2).

Visual Basic 2008 merupakan aplikasi pemrograman yang menggunakan teknologi Net Framework. Teknologi.Net Framework merupakan komponen Windows yang terintegrasi serta mendukung pembuatan, penggunaan aplikasi, dan halaman web. Teknologi.Net Framework mempunyai 2 komponen utama yaitu CLR (Common Language Runtime) dan Class Library. CLR digunakan untuk menjalankan aplikasi yang berbasis.Net, sedangkan Library adalah kelas pustaka atau perintah yang digunakan untuk membangun aplikasi(Wahana Komputer, 2010:h.2).

\section{3) $\mathrm{MySQL}$} Management System) Perangkat lunak ini bermanfaat untuk mengelola data dengan cara yang sangat fleksibel dan cepat. Berikut adalah sejumlah aktivitas yang terkait dengan data yang didukung oleh perangkat lunak tersebut.

1. Menyimpan data kedalam tabel

2. Menghapus data dalam tabel

3. Mengubah data dalam tabel

4. Mengambil data yang tersimpan dalam tabel. (Abdul Kadir,2010:h.10).

MySQL merupakan sistem manajemen database yang bersifat relational. Artinya, data yang dikelola dalam database akan diletakkan pada beberapa tabel yang terpisah sehingga manipulasi data akan menjadi jauh lebih cepat. Mysql dapat digunakan untuk mengelola database mulai dari yang kecil sampai dengan yang sangat besar (Ignas, 2014:h.73).

\section{4) Crystal Report}

Crystal Report merupakan salah satu aplikasi software yang digunakan secara khusus untuk membantu developer dalam merancang laporan. Sejak tahun 1993, Crystal Report sudah menjadi bagian dari Microsoft Visual Studio yang digunakan sampai saat ini sebagai standar merancang laporan dalam pembangunan sebuah sistem.

Crystal Report juga merupakan salah satu aplikasi khusus yang digunakan untuk merancang berbagai jenis laporan. Pertama kali Crystal Report diciptakan oleh Cristal Services Inc untuk menemukan seorang developer yang khusus menangani pembuatan report untuk software aplikasi akuntansi yang Cristal Servise Inc kembangkan (Irnawan, 2011:h.1).

Berikut beberapa fitur keunggulan Crystal Report dengan dibandingkan aplikasi lain yang sejenis fungsi dan kegunaannya (Irnawan, 2011:h.2)

1) Crystal Reportmerupakan software aplikasi yang berbasis GUI (graphical user interface)

2) Crystal Reportdapat terkoneksi dengan mudah dengan berbagai macam database.

3) Crystal Reportmengenal hampir semua Driver dari berbagai macam database.

4) Mempunyai berbagai macam fasilitas export kedalam beberapa aplikasi pengolah data dan angka.

5) Setting margin yang tidak harus menggunakan coding program.

6) Disediakan fasilitas untuk menggunakan vipot tabel.

7) Dapat menampilkan report dalam bentuk Grafik. 
8) Mengurangi banyak Coding dalam pembuatan program.

9) Disediakan banyak fungsi (financial, aritmatika, date/times, array, string, dan lain-lain) dan tools (label, group, formula, parameter, running total field, special field, group name field dll) yang bertujuan untuk mempermudah pembuatan report.

10) Dapat berjalan disemua tipe printer tanpa perlu menambahkan coding program (laser jet, printonix, deskjet, dotmatrix).

11) Mengenal setting kertas diluar jenis kertas standart yang ada di windows.

12) Dapat mengenal tipe huruf untuk di sistem operasi atau lebih.

13) Dapat bekerja menggabungkan dari satu atau dua report dalam satu report baru

\section{5) Komputerisasi}

Sistem komputerisasi adalah penggunaan komputer sebagai alat Bantu dalam kegiatan pengolahan data yang dilakukan secara manual. Data diolah dengan menggunakan computer yang sudah deprogram sebelumnya, pengolahan data ini dimulai dengan perekam data hingga sampai pada pencetakan laporan (Jogiyanto, 1999).

Pengolahan data secara komputerisasi lebih menguntungkan dibandingkan dengan pengolahan data secara manual. Keuntungan tersebut dapat ditinjau dari beberapa segi. Salah satu dalam hal penyajian laporan yang lebih cepat dan efisien dan akurat. Faktor keuntungan inilah yang menjadi alasan mengapa pengolahan data dilakukan secara komputerisasi untuk menggantikan sistem manual. sudah ada terdapat kendala) baik sebagian maupun secara keseluruhan atau menyusun sistem yang baru dari sistem yang sebelumnya manual menjadi sistem yang terkomputerisasi dengan meningkatkan kemampuan mesin komputer dan sumber daya manusia secara lebih efisien.

\section{6) Data Flow Diagram (DFD).}

Data Flow Diagramsering digunakan untuk menggambarkan suatu sistem yang telah ada atau sistem baru yang akan dikembangkan secara logika tanpa mempertimbangkan lingkungan fisik dimana data tersebut mengalir atau lingkungan fisik dimana data tersebut akan disimpan (misalnya file kartu, microfile, harddisk, tape, disket dan lain sebagainya). DFD merupakan alat yang cukup populer sekarang ini, karena dapat menggambarkan arus data di dalam sistem dengan terstruktur dan jelas. Data Flow Diagram mempunyai komponen dasar berupa empat buah simbol sebagai berikut (Deddy Kusbianto,2010;h.44) :
Tabel 1. Simbol-simbol pada Data Flow Diagram menurut Gane dan Serson

\begin{tabular}{|c|l|}
\hline Simbol & \multicolumn{1}{c|}{ Keterangan } \\
\hline & $\begin{array}{l}\text { External Entity; digunakan } \\
\text { untuk menggambarkan asal } \\
\text { atau tujuan data }\end{array}$ \\
\hline & $\begin{array}{l}\text { Proses ; digunakan untuk } \\
\text { proses } \\
\text { pengolahanatautransformasi } \\
\text { data }\end{array}$ \\
\hline$\square$ & $\begin{array}{l}\text { Data Store; digunakan untuk } \\
\text { menggambarkan Penyimpanan } \\
\text { Data }\end{array}$ \\
\hline$\longrightarrow$ & $\begin{array}{l}\text { Data Flow; digunakan untuk } \\
\text { menggambarkan aliran data } \\
\text { atau Arus Data }\end{array}$ \\
\hline
\end{tabular}

Sumber : Deddy Kusbianto, 2010

\section{7) Entity Relationship Diagram (ERD)}

ER (Entuty-Relationship) merupakan model data tingkat tinggi yang popular untuk model data relasional. Model ini dengan sejumlah variasinya sering digunakan dalam desain konseptual dari aplikasi basis data. Dalam ER model, skema konseptual untuk suatu aplikasi basis data ditunjukkan dengan menggunakan notasi - notasi grafis yang disebut ERD (Deddy Kusbianto, 2010:h.84)

\section{METODE PENELITIAN}

Pembahasan dan penyelesaian penelitian ini dilakukan dengan mengikuti kerangka kerja berikut ini :

\section{1). Mengumpulkan Data}

Pengumpulan data diambil dari berbagai sumber dengan tiga metode, yaitu studi permasalahan, metode observasi dan wawancara.

a. Studi Permasalahan

Studi masalah dilakukan denganmempelajari

data yang diberikan oleh pegawai dari semua ruangan.

b. Observasi

Observasi atau pengamatan, yaitu suatu teknik pengumpulan data yang diperoleh dengan cara mengadakan pengamatan dan peninjauan secara langsung kepada objek penelitian yaitu padaKLH dikota Dumai.

c. Wawancara

Wawancara, yaitu suatu teknik pengumpulan data yang dilakukan dengan mengadakan tanya jawab secara langsung kepada staff inventaris yang berhubungan langsung dengan masalah yang diteliti (Sugiyono, 2011; h.317).

2. Mengidentifikasi Masalah 
IN F ORMA T I K A

Jurnal Informatika, Manajemen Dan Komputer Vol. 9 No. 1, Mei 2017

eISSN : 2580-3042

pISSN : 1979-0694

Tahapan ini dimulai dengan melakukan survey ke lapangan dan melihat secara langsung bagaimana cara pendataan barang inventaris, dan juga pengecekan kondisi barang dan laporan.

3. Mempelajari literatur

Mempelajari jurnal-jurnal serta buku-buku yang berhubungan dengan permasalahan yang ada.

4. Menganalisis Masalah

Analisis masalah pada penelitian ini dilakukan dengan metode deskriptif dimana pada metode ini data yang ada dikumpulkan, disusun, dikelompokkan dan dianalisa sehingga diperoleh beberapa gambaran yang jelas pada permasalah yang dibahas.

5. Mendesain sistem

Pada tahap ini akan dilakukan proses desain sistem, dimulai dengan penyajian basis data, desain antar muka masukan, pembuatan flowchart program dan pembuatan antar muka keluaran.

6. Membangun sistem.

Membangun suatu sistem dengan melihat dari permasalahan yang ada maka dapat ditentukan kebutuhan-kebutuhan apa saja yang nantinya akan digunakan untuk menentukan barang inventaris dan ruangan serta kondisi barang.

7. Mengimplementasi sistem.

Pada tahap ini dilakukan pengkajian kembali kelayakan dari pada sistem aplikasi yang di rancang. Apakah sistem tersebut sudah sesuai atau masih perlu dilakukan peninjauan kembali atau penyempurnaan.

8. Menguji sistem.

Pengujian hasil dilakukan dengan :

a. Melakukan pengolahan data secara manual.

b. Melakukan testing/pengujian hasil pengolahan data secara manual.

c. Melakukan pengujian data menggunakan bahasa pemrograman visual basic net dan database $M y s q l$.

d. Membandingkan hasil pengolahan data secara manualdengan hasil pengolahan data menggunakan pemrograman Visual Basic Net database MySql.

\section{HASIL DAN PEMBAHASAN}

\subsection{Analisa Sistem Yang Sedang Berjalan}

Berikut ini merupakan keterangan dari gambar 1, tentang aliran sistem informasi data barang inventaris yang sedang berjalan padaKLH Kota Dumai :

1. Pengguna melaporkan kondisi penggunaan barang inventaris secara berkala kepada pengurus barang.

2. Pengurus barang menerima barang untuk ditempatkan di setiap ruangan, dan mencatat barang inventaris yang diperlukan ke dalam kartu inventaris ruangan sebanyak 3 rangkap, untuk disimpan didalam arsip, untuk pengguna dan untuk kepala kantor.

3. Pengurus barang mendistribusikan barang pada semua ruangan. Dan membuat laporan penggunaan barang secara berkala sebanyak 3 rangkap, untuk disimpan didalam arsip, untuk pengguna dan untuk kepala kantor.

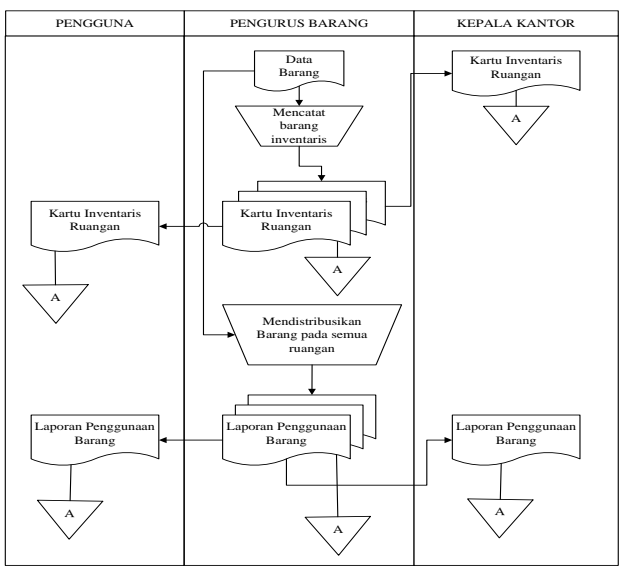

Gambar 1. Aliran sistem informasi

\subsection{Aliran Sistem Informasi Baru}

Aliran sistem data barang inventaris pada KLH Kota Dumai yang baru mengalami perubahan dari sistem yang lama, karena pada sistem yang baru sudah menggunakan database sebagai media penyimpanan dan seluruh kegiatan input data dilakukan oleh bagian pengurus barang, sehingga memudahkan dalam proses pembuatan laporan yang cepat dan akurat. Aliran sistem informasi yang baru dapat dilihat pada gambar 2 . 
IN F O RM A I I A

Jurnal Informatika, Manajemen Dan Komputer Vol. 9 No. 1, Mei 2017

eISSN : 2580-3042

pISSN : 1979-0694

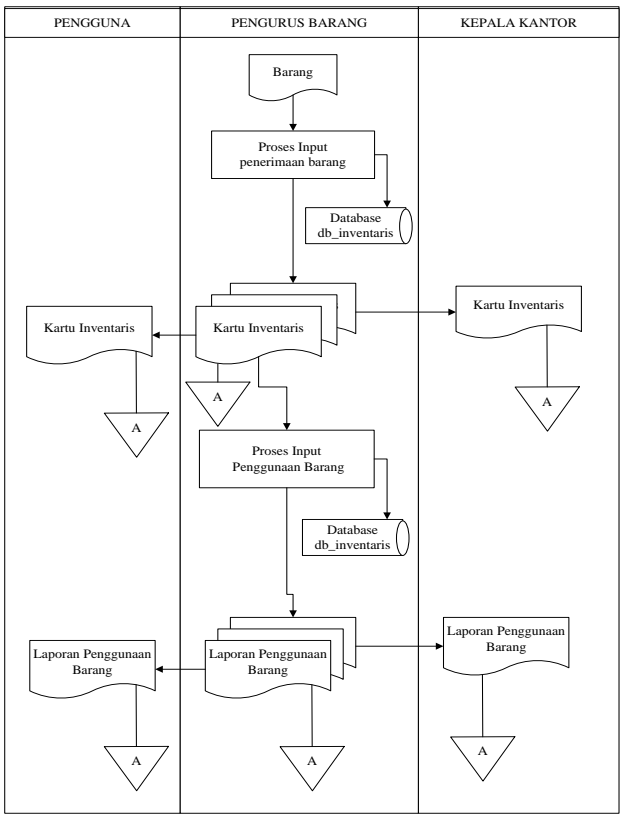

Gambar 2. Aliran sistem informasi baru

\subsection{Perancangan Sistem}

1). Context Diagram

Agar sistem baru yang diusulkan dapat tergambar dengan jelas, perlu dijabarkan dalam context diagram seperti pada gambar 3 dibawah ini.

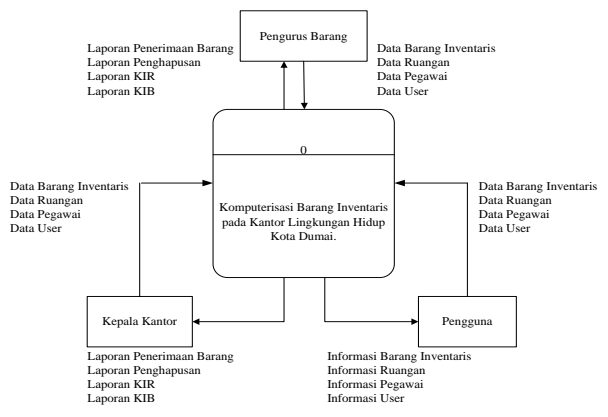

Gambar 3. Context diagram

\section{2). DFD (Data Flow Diagram)}

DFDmerupakan penjabaran bagaimana data mengalir dalam context diagrammelalui proses yang saling berkaitan dengan menggunakan symbol-simbol. Dalam merancang suatu proses perlu menggunakan DFD. Dengan mengacu kepadaContext Diagram maka dapatmemperjelas proses data yang bergerak dari input ke output..

Berikut adalah Proses Perencanaan DFD Sistem komputerisasi Inventaris di KLH kota Dumai.
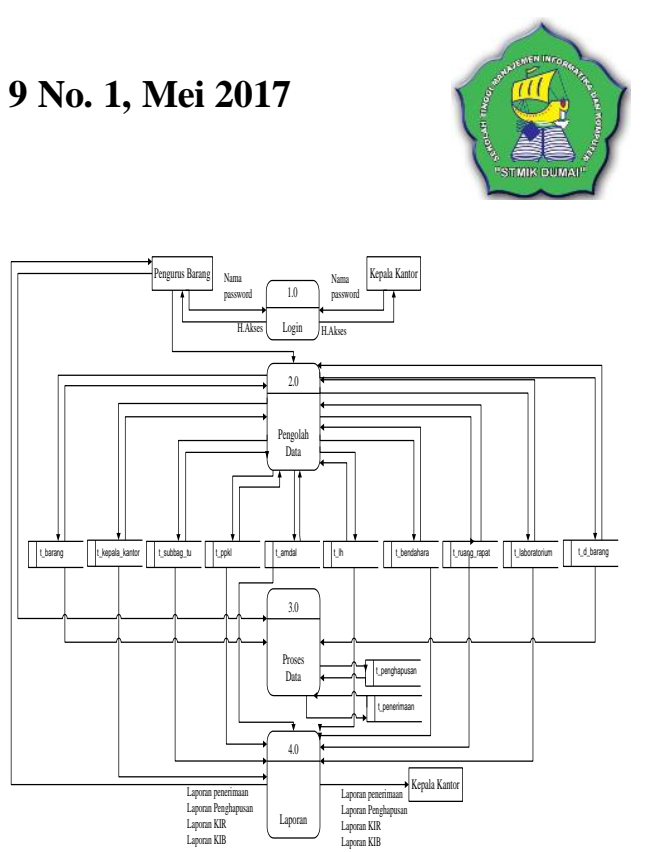

Gambar 4. Data flow diagram

3). Entity Relation Diagram (ERD)

Entity Relationship Diagram merupakan diagram yang mengambarkan hubungan antara entity dalam sebuah database. Diagram dibawah ini memperlihatkan hubungan antar file dalam sistem inventaris yang dirancang. Untuk lebih jelasnya dapat digambarkan seperti gambar 5 .

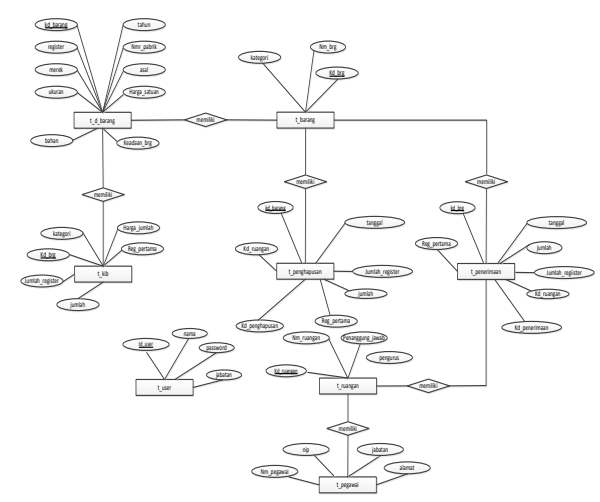

Gambar 5. Entity relationshipdiagram

\subsection{Perancangan Input}

1) Form Login

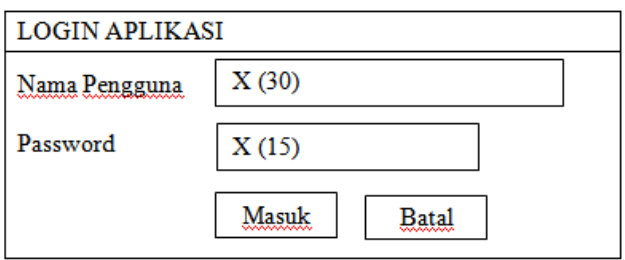

Gambar 6. Form login

2). Form Input Barang Inventaris 
I N F ORM T I K A

Jurnal Informatika, Manajemen Dan Komputer Vol. 9 No. 1, Mei 2017

eISSN : 2580-3042

pISSN : 1979-0694

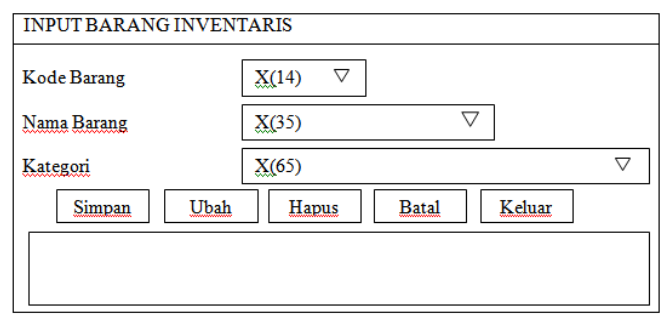

Gambar 7. Form inputbarang inventaris

3). Form InputRuangan

\begin{tabular}{|c|c|c|c|c|}
\hline \multicolumn{5}{|c|}{ INPUT RUANGAN } \\
\hline \multicolumn{2}{|l|}{ Kode Ruangan } & $\mathrm{x}(15)$ & $\nabla$ & \\
\hline \multicolumn{2}{|l|}{ Nama Ruangan } & $\mathrm{X}(30)$ & & \\
\hline \multicolumn{2}{|l|}{ Penanggung Jawab } & $\mathrm{X}(20)$ & $\nabla$ & $\mathrm{X}(20)$ \\
\hline \multicolumn{2}{|l|}{ Pengurus } & $\mathrm{X}(20)$ & $\nabla$ & $\mathrm{X}(20)$ \\
\hline Simpan & Ubah & Hapus & Batal & Keluar \\
\hline
\end{tabular}

Gambar 8. Form InputRuangan

4). Form InputPenerimaan Barang Inventaris

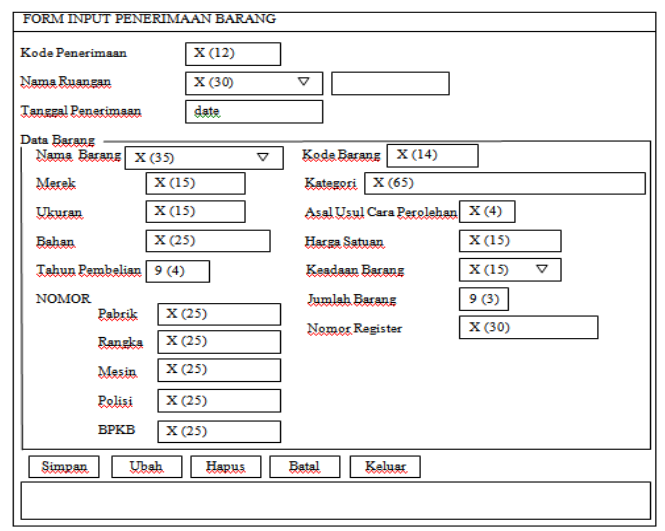

Gambar 9. Form inputpenerimaan baranginventaris

\subsection{Perancangan Output}

1) Tabel 2. Perancangan Output Penerimaan Barang

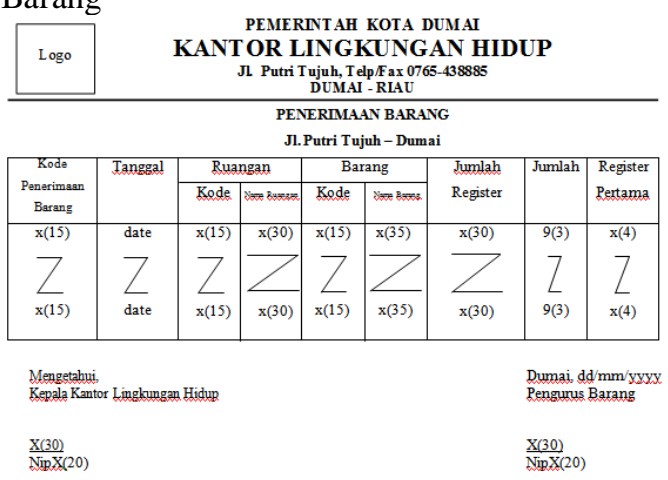

2) Tabel 3. Perancangan Output Ruangan

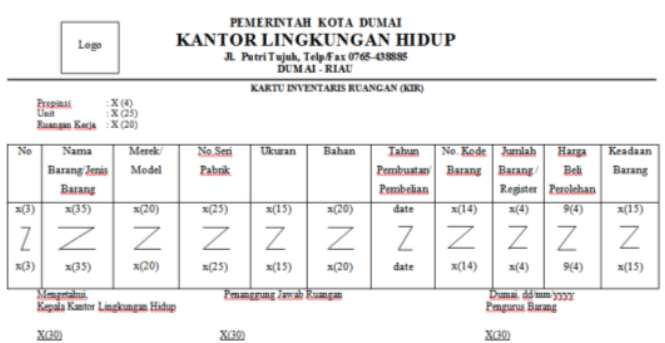

3.6 Implementasi Sistem

1). Form Login

Jika Koneksi sukses atau terhubung keserver maka akan muncul form login aplikasi. Masukkan nama pengguna dan password. Jika telah di isi dengan benar, maka program aplikasi utama terbuka.

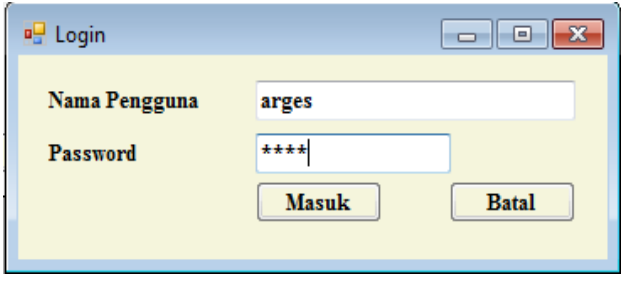

Gambar 10. Form login

\section{2). FormMenu Utama}

Pada menu utama yang terdapat pada program, terdapat beberapa submenu yang memiliki fungsi dan kegunaan masing-masing. Klik submenu Data Master untuk menginput data barang inventaris, data ruangan, data pegawai. Klik menu transaksi untuk melakukan transaksi seperti data penerimaan, data penghapusan. Klik menu laporan untuk menampilkan berbagai macam jenis laporan. Klik submenu keluar jika ingin keluar dari aplikasi.

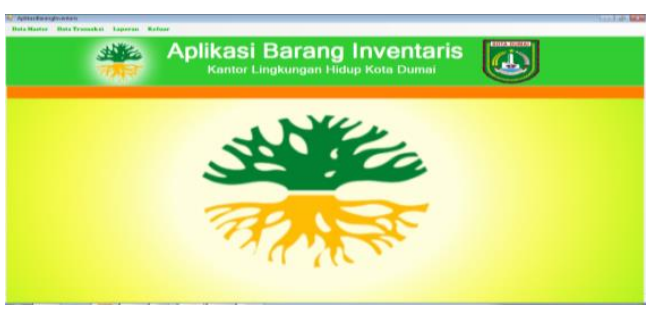

Gambar 11. Formmenu utama

3). Form InputBarang Inventaris

Pada menu data master klik submenu barang inventaris dan akan tampil form input barang inventaris sebagai berikut : 
I N F ORM T I K A

Jurnal Informatika, Manajemen Dan Komputer Vol. 9 No. 1, Mei 2017

eISSN : 2580-3042

pISSN : 1979-0694

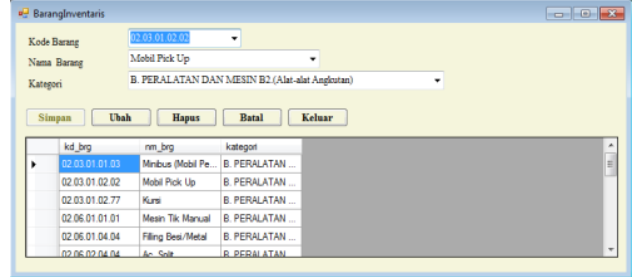

Gambar 12.Forminputbarang inventaris

Silahkan input data pada setiap objek yang ada di form kemudian klik tombol simpan. Jika untuk mengedit data silahkan isi objek yang ingin dikoreksi kemudian lakukan pengeditan dengan cara klik pada tombol ubah. Untuk menghapus data barang inventaris silahkan klik tombol hapus, untuk menghapus data dari database.Selanjutnya membatalkan penginputan data silahkan klik tombol batal.Dan untuk keluar dari form ini klik tombol tutup.

\section{4). Form InputRuangan}

Pada menu data master klik submenu ruangan dan akan tampil form input ruangan sebagai berikut

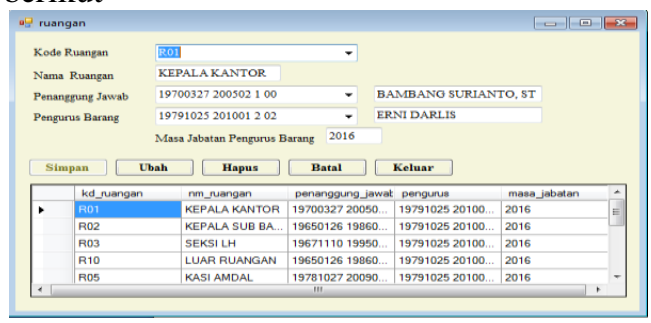

Gambar 13. Forminputruangan

Silahkan input data pada setiap objek yang ada di form kemudian klik tombol simpan. Jika untuk mengedit data silahkan isi objek yang ingin dikoreksi kemudian lakukan pengeditan dengan cara klik pada tombol ubah. Untuk menghapus data ruangan silahkan klik tombol hapus, untuk menghapus data dari database. Selanjutnya membatalkan penginputan data silahkan klik tombol batal. Dan untuk keluar dari form ini klik tombol tutup.

\section{5). FormInput Pegawai}

Pada form ini digunakan untuk melakukan penginputan ruangan, adapun cara penginputannya adalah sebagai berikut :

Pada menu data master klik submenu pegawai dan akan tampil form input barang inventaris sebagai berikut :

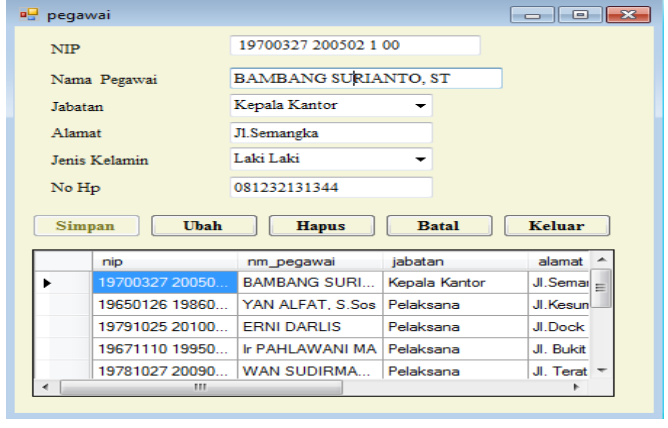

Gambar 14. Forminputpegawai

Silahkan input data pada setiap objek yang ada di form kemudian klik tombol simpan. Jika untuk mengedit data silahkan isi objek yang ingin dikoreksi kemudian lakukan pengeditan dengan cara klik pada tombolubah. Untuk menghapus data pegawai silahkan klik tombol hapus, untuk menghapus data dari database. Selanjutnya membatalkan penginputan data silahkan klik tombol batal. Dan untuk keluar dari form ini klik tombol tutup.

6). FormTransaksi Penerimaan Barang

Pada menu transaksi klik submenu penerimaan dan akan tampil form input barang inventaris sebagai berikut :

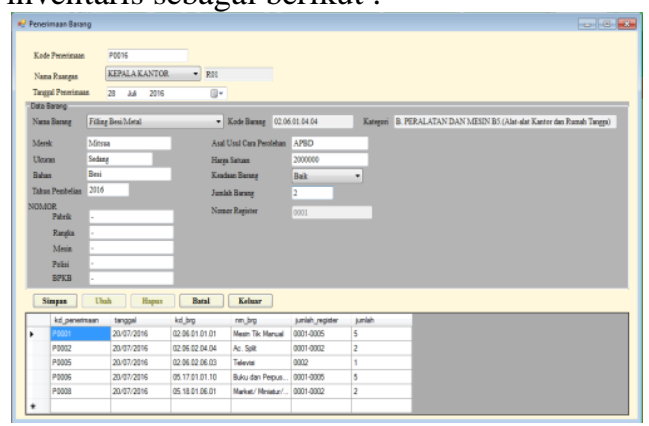

Gambar 15. Form tansaksipenerimaan barang

Kemudian silahkan input data pada setiap objek yang ada di form kemudian klik tombol simpan. Jika untuk mengedit data silahkan isi objek yang ingin dikoreksi kemudian lakukan pengeditan dengan cara klik pada tombol ubah. Untuk menghapus data penghapusan silahkan klik tombol hapus, untuk menghapus data dari database. Selanjutnya membatalkan penginputan data silahkan klik tombol batal. Dan untuk keluar dari form ini klik tombol tutup.

6). Form TransaksiPenghapusan

Pada menu transaksi klik submenu penghapusan dan akan tampil form input barang inventaris sebagai berikut : 
I N F ORM T I K A

Jurnal Informatika, Manajemen Dan Komputer Vol. 9 No. 1, Mei 2017

eISSN : 2580-3042

pISSN : 1979-0694

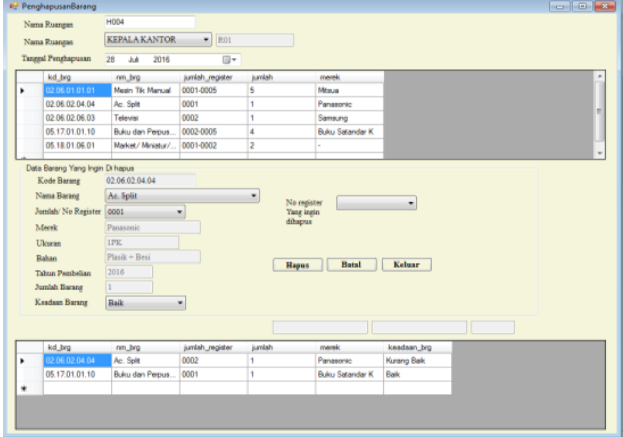

Gambar 16. Formtransaksi penghapusan

Kemudian silahkan input data pada setiap objek yang ada di form kemudian klik tombol simpan. Jika untuk mengedit data silahkan isi objek yang ingin dikoreksi kemudian lakukan pengeditan dengan cara klik pada tombol ubah. Untuk menghapus data penerimaan barang silahkan klik tombol hapus, untuk menghapus data dari database. Selanjutnya membatalkan penginputan data silahkan klik tombol batal. Dan untuk keluar dari form ini klik tombol tutup.

7). Laporan Penerimaan Barang

Laporan penerimaan barang berguna untuk menampilkan seluruh inventaris barang berdasarkan kode penerima barang, tanggal terima, kode ruangan, nama ruangan, kode barang, nama barang, jumlah register jumlah barang serta harga barang, seperti pada gambar 17.

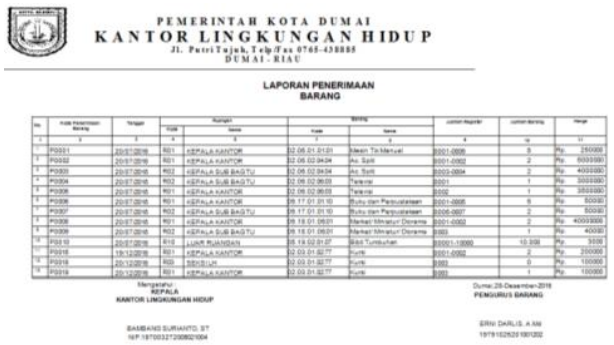

Gambar 17. Laporan penerimaan barang

8) Laporan Penghapusan Barang

Untuk menampilkan danmencetak Laporan Penghapusan atau data Perbaikan barang maka dapat dilakukandengan cara klik menu Laporan dankemudian pilih Laporan Penghapusan Barang, lalu inputkan/pilih tahun anggaran dan ruangan, sebagai bentuk laporan dan persetujuan, di bawah tabel laporan sudah diinputkan terlebih dahulu nama pengurus barang dan nama kepala KLH.Jika sudahklik Lihat, maka akan tampil laporanpenghapusan barang sepertipada gambar 18

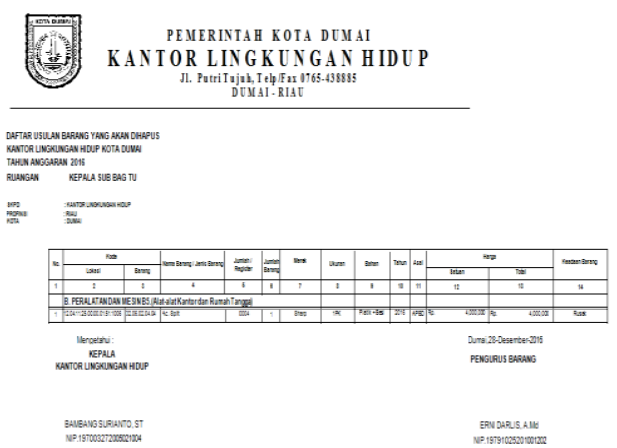

Gambar 18. Laporan penghapusan barang

9). Laporan Kartu Inventaris Ruangan (KIR)

Untuk menampilkan danmencetak laporan data inventaris per kode ruangan makadapat dilakukan dengan cara klikmenu laporan dan kemudian pilihlap. KIR, selanjutnya menginputkan unit ruangan kerja, menginputkan nama pengurus barang, menginputkan penanggung jawab barang, dan nama kepala kantor sebagai bentuklaporan dan persetujuan daripimpinan, jika sudah klik lihat, makaakan tampil laporan datapenempatan insventaris per koderuangan seperti pada gambar 19.
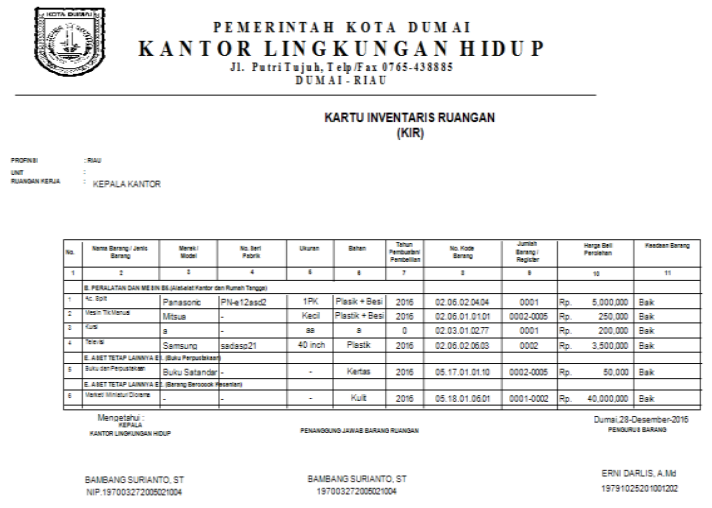

Gambar 19. Laporan KIR

9). Laporan Kartu Inventaris Barang (KIB)

Untuk menampilkan danmencetak laporan data inventaris per kode barang makadapat dilakukan dengan cara klikmenu laporan dan kemudian pilih lap. KIB, menginputkan nama pengurus barang, dan nama kepala kantor sebagai bentuklaporan dan persetujuan daripimpinan, jika sudah klik lihat, makaakan tampil laporan data penempatan insventaris per kodebarang seperti pada gambar 20. 
I N F ORM T I K A

Jurnal Informatika, Manajemen Dan Komputer Vol. 9 No. 1, Mei 2017

eISSN : 2580-3042

pISSN : 1979-0694

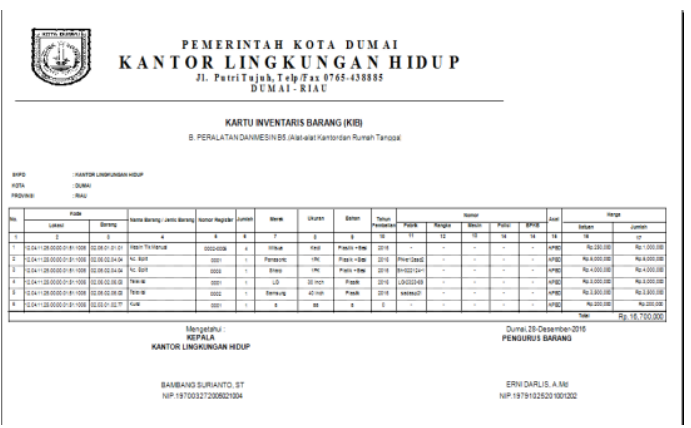

Gambar 20. Laporan KIB

10). Laporan Cetak Stiker Barang

Untuk menampilkan danmencetak stiker makadapat dilakukan dengan cara klikmenu laporan dan kemudian pilih cetak stiker barang. Selanjutnya inputkan kode lokasi dengan cara mengklik, karena data kode lokasi sebelumnya sudah diinputkan, masukan kode barang, untuk memasukan kode barang cukup dengan mengklik nama barang, dan berikutnya klik nomor register. seperti pada gambar 21 dibawah ini.

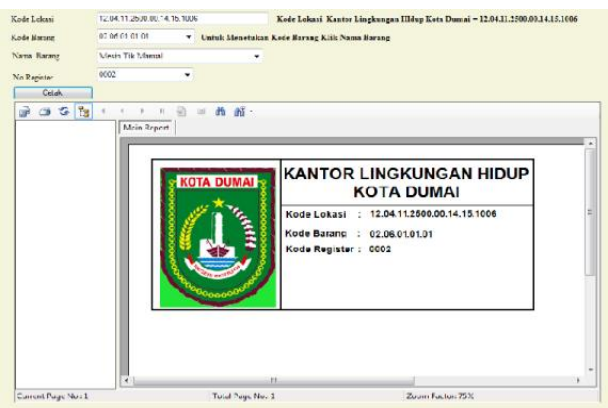

Gambar 21. Laporan cetak stiker barang

11). Laporan Keadaan Barang

Untuk menampilkan dan mencetak laporan data keadaan barang inventarismaka dapat dilakukan dengan cara klik menu laporan dan kemudian pilih laporan keadaan barang, maka akan tampil laporan data keadaan barang inventaris seperti pada gambar 22 .

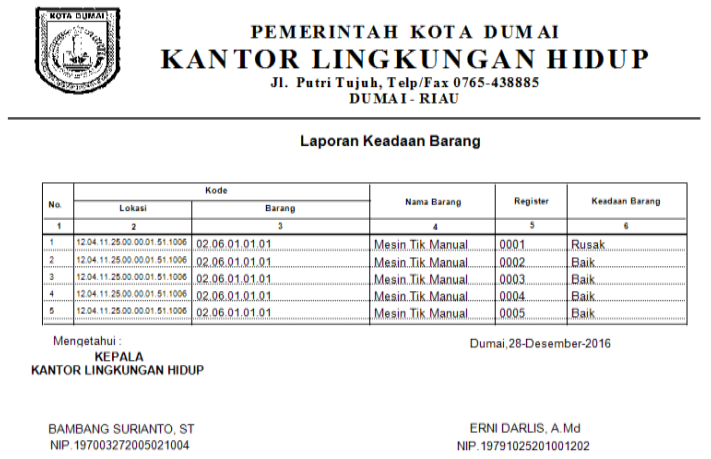

\section{SIMPULAN}

Berdasarkan proses penelitian yang dilakukan dan permasalahan-permasalahan yang ditemukan, maka penulis menyimpulkan bahwa penerapan sistemkomputerisasi inventaris barang yang berbasis database pada kantor lingkungan hidup kota Dumai perlu dilakukan sehingga penatausahaan inventaris barang milik/kekayaan negara dapat berjalan secara optimal.Outputkomputerisasi data inventaris yang dihasilkan berupa laporanlaporanyang lebih cepat, tepat dan akurat yang diperlukan bagi semua yang berkepentinganterutama bagi petugas inventaris dan pimpinan untuk pertanggungjawaban dan pengambilan keputusan.

\section{REFERENSI}

Abdul Kadir. (2010). Mudah Mempelajari Database MySQL. Andi Offset. Yogyakarta.

Chabib, Soleh dan Rochmansjah, Heru. (2010).Pengelolaan Keuangan dan Aset Daerah. Bandung: Fokusmedia.

Deddy Kusbianto. (2010). Analisis \& Perancangan Sistem Informasi. STMIK Yadika. Bangil

Jogiyanto, HM. (1999). Pengenalan Komputer. Andi. Yogyakarta.

Ignas. (2014). Sistem Informasi Penjualan Online Untuk Tugas Akhir. Andi. Yogyakarta

Irnawan. (2011). Step By Step Merancang dan Membangun Sistem Komputerisasi. Jakarta: Elexmedia Komputindo

Peraturan Menteri Dalam Negeri Nomor 17 Tahun 2007 tentang Pedoman Teknis Pengelolaan Barang milik Daerah. Diakses November 16, 2016 dari http://bpkad.banjarkab.go.id/index.php/2 015/06/29/inventarisasi-barang-milikdaerah/

Sugiyono, (2011). Metode Penelitian Pendidikan. (Pendekatan Kuantitatif, Kualitatif, dan $R \& D)$. Bandung: Alfabeta.

Wahana Komputer. (2010). Membuat Aplikasi Client Server dengan Visual Basic 2008. Andi. Yogyakarta.

Gambar 22. Laporan keadaan barang 